\title{
Development of a Raoult's Law-Based Screening-Level Risk Assessment Methodology for Coal Tar and Its Application to Ten Tars Obtained from Former Manufactured Gas Plants in the Eastern United States
}

\author{
Derick G. Brown \\ Department of Civil and Environmental Engineering, Lehigh University, Bethlehem, USA. \\ Email: dgb3@lehigh.edu \\ Received April $8^{\text {th }}, 2013$; revised May $2^{\text {nd }}, 2013$; accepted June $1^{\text {st }}, 2013$ \\ Copyright (C) 2013 Derick G. Brown. This is an open access article distributed under the Creative Commons Attribution License, \\ which permits unrestricted use, distribution, and reproduction in any medium, provided the original work is properly cited.
}

\begin{abstract}
A Raoult's law-based screening-level assessment methodology was developed to calculate the carcinogenic and noncarcinogenic risks from ingestion of coal tar-contaminated water and it was applied to ten coal tars obtained from sites in the eastern United States. This approach provides a simple risk screening based on the conservative assumptions of Tier 1 in both the ASTM RBCA methodology and the USEPA Soil Screening Guidance. Results across the ten tars exhibited similar patterns, even though the coal tars had significantly different chemical compositions, and in all cases the screening-level risks were above the USEPA thresholds. There was no appreciable difference in the total risks when using either the current USEPA 1993 PAH risk assessment guidance or the proposed 2010 guidance. Benzene, while present at low concentrations within the coal tars, posed the dominant risk and strong correlations were observed with the benzene mole fraction.
\end{abstract}

Keywords: Raoults Law; Coal Tar; Manufactured Gas Plant; BTEX; PAH; Carcinogen

\section{Introduction}

The manufactured gas process was widely used throughout the United States and Europe from the early-1800's through the mid-1900's [1-7]. This process involves heating materials such as coal, oil or wood in the absence of oxygen and capturing the gas that is released. The manufactured gas produced from this process was used for heating, cooking, and lighting. It had a tremendous impact on the quality of life and was a key contributor to the industrial revolution [7]. The manufactured gas industry began to decline upon the development of natural gas and electrical energy [7] and these manufactured gas plants (MGPs) have subsequently been razed. These former MPG sites, many of which are now often owned by either utility companies or municipalities, are often located adjacent to residential areas and many have new structures built on top of them. The exact number of former MGP sites is unknown, but estimates in the United States alone range from 1500 [3,5] to over 32,000 [2]. Except for the environmental professionals and local residents dealing with its aftermath, the manufactured gas industry is today largely forgotten by the general public.

Coal was the most commonly-used material by the manufactured gas industry [7] and a byproduct of the gasification process is a dense non-aqueous phase liquid (dense NAPL, or DNAPL) typically referred to as coal tar. Coal tar is composed of hundreds to thousands of organic compounds, mostly polycyclic aromatic hydrocarbons (PAHs) [8-10]. As a bulk material, coal tar properties vary widely, with reported average molecular weights ranging from 230 to $3213 \mathrm{~g} / \mathrm{mole}$ and viscosities ranging from free-flowing to a semi-solid state $[11,12]$. Additionally, the physical and chemical properties of the individual constituents that make up coal tar span many orders of magnitude [13-15] (see Table 1). A result of these wide ranges of bulk and constituent properties is that coal tar DNAPL is difficult to remediate once released into the environment and it tends to persist for a long time [1,16,17].

Due to past handling and storage practices, it is be- 
Table 1. Properties of toxic and carcinogenic compounds identified in the coal tars.

\begin{tabular}{|c|c|c|c|c|c|c|c|}
\hline Compound & $\begin{array}{l}\text { Chemical } \\
\text { Formula }\end{array}$ & $\begin{array}{c}\text { MW } \\
\text { (g/mole) }\end{array}$ & $\begin{array}{c}\text { Aqueous } \\
\text { Solubility }^{(\mathrm{a}, \mathrm{b})} \\
\text { (mg/L) }\end{array}$ & $\begin{array}{l}\text { Fugacity } \\
\text { Ratio }^{(b, c)}\end{array}$ & $\begin{array}{l}\text { Slope factor } \\
\left(\mathrm{mg} / \mathbf{k g}^{(\mathrm{d})}\right)^{-1}\end{array}$ & $\begin{array}{c}\text { Relative Potency } \\
\text { Factor }^{(\mathrm{e})}\end{array}$ & $\begin{array}{c}\text { Oral RfD }^{(d)} \\
(\mathrm{mg} / \mathbf{k g}-\mathrm{d})\end{array}$ \\
\hline Benzene & $\mathrm{C}_{6} \mathrm{H}_{6}$ & 78 & 1780 & 1 & 0.055 & & 0.004 \\
\hline Toluene & $\mathrm{C}_{6} \mathrm{H}_{5} \mathrm{CH}_{3}$ & 92 & 515 & 1 & & & 0.08 \\
\hline Ethylbenzene & $\mathrm{C}_{6} \mathrm{H}_{5} \mathrm{C}_{2} \mathrm{H}_{5}$ & 106 & 152 & 1 & & & 0.1 \\
\hline $\mathrm{m} / \mathrm{p}$-Xylenes & $\mathrm{C}_{6} \mathrm{H}_{4}\left(\mathrm{CH}_{3}\right)_{2}$ & 106 & 180 & 1 & & & 0.2 \\
\hline Styrene & $\mathrm{C}_{6} \mathrm{H}_{5} \mathrm{C}_{2} \mathrm{H}_{3}$ & 104 & 300 & 1 & & & 0.2 \\
\hline 0 -Xylene & $\mathrm{C}_{6} \mathrm{H}_{4}\left(\mathrm{CH}_{3}\right)_{2}$ & 106 & 130 & 1 & & & 0.2 \\
\hline Naphthalene & $\mathrm{C}_{10} \mathrm{H}_{8}$ & 128 & 31 & 0.31 & & & 0.02 \\
\hline 2-Methylnaphthalene & $\mathrm{C}_{11} \mathrm{H}_{10}$ & 142 & 25 & 0.86 & & & 0.004 \\
\hline Acenaphthene & $\mathrm{C}_{12} \mathrm{H}_{10}$ & 154 & 3.8 & 0.2 & & & 0.06 \\
\hline Fluorene & $\mathrm{C}_{13} \mathrm{H}_{10}$ & 166 & 1.9 & 0.16 & & & 0.04 \\
\hline Anthracene & $\mathrm{C}_{14} \mathrm{H}_{10}$ & 178 & 0.05 & 0.01 & & & 0.3 \\
\hline Fluoranthene & $\mathrm{C}_{16} \mathrm{H}_{10}$ & 202 & 0.26 & 0.21 & & $0(0.08)$ & 0.04 \\
\hline Pyrene & $\mathrm{C}_{16} \mathrm{H}_{10}$ & 202 & 0.13 & 0.11 & & & 0.03 \\
\hline Benz[a]anthracene & $\mathrm{C}_{18} \mathrm{H}_{12}$ & 228 & 0.011 & 0.04 & & $0.1(0.2)$ & \\
\hline Chrysene & $\mathrm{C}_{18} \mathrm{H}_{12}$ & 228 & 0.002 & 0.01 & & $0.001(0.1)$ & \\
\hline Benzo[b]fluoranthene & $\mathrm{C}_{18} \mathrm{H}_{12}$ & 252 & 0.0015 & 0.039 & & $0.1(0.8)$ & \\
\hline Benzo[k]fluoranthene & $\mathrm{C}_{20} \mathrm{H}_{12}$ & 252 & 0.0008 & 0.013 & & $0.01(0.03)$ & \\
\hline Benzo[a]pyrene & $\mathrm{C}_{20} \mathrm{H}_{12}$ & 252 & 0.004 & 0.03 & 7.3 & 1 & \\
\hline Indeno $[1,2,3-\mathrm{cd}]$ pyrene & $\mathrm{C}_{22} \mathrm{H}_{12}$ & 276 & 0.062 & 0.045 & & $0.1(0.07)$ & \\
\hline Dibenz[a,h]anthracene & $\mathrm{C}_{22} \mathrm{H}_{14}$ & 278 & 0.0005 & 0.004 & & $1(10)$ & \\
\hline Benzo[g,h,i]perylene & $\mathrm{C}_{22} \mathrm{H}_{12}$ & 276 & 0.0003 & 0.003 & & $0(0.009)$ & \\
\hline
\end{tabular}

(a) From Reference [14]; (b) Temperature $=25^{\circ} \mathrm{C}$; (c) From Reference [13]; (d) USEPA IRIS database [20]; (e) Following the USEPA 1993 Guidance document [19] or the USEPA 2010 Draft Technical Document (http://www.epa.gov/risk/) (values in parentheses).

lieved there is residual coal tar at most former MGP sites $[1,2,5,6,17]$ and this coal tar is a long-term source of contamination to groundwater supplies. This contamination is of concern as the U.S. Environmental Protection Agency (USEPA) and the National Institute of Environmental Health Sciences have classified a number of PAHs as probable human carcinogens [18-20]. Benzene, a known human carcinogen $[18,20]$, is also typically found in coal tars. In addition to the carcinogens, coal tar also contains a number of monocyclic aromatic hydrocarbons (MAHs) and PAHs that are known to have toxic health effects [20]. The toxic and carcinogenic MAHs and PAHs commonly found in coal tars are presented in Table 2.

Given the large number of potential coal tar contaminated sites, there is surprisingly a dearth of information on coal tar risk assessments. An animal study was performed on carcinogenic effects of composite mixtures of several coal tars directly fed to mice [21]. These coal tar mixtures had a high concentration of Benzo(a)pyrene $(\mathrm{BaP})$, which is a suspected human carcinogen [18-20], and the calculated slope factor was in agreement with the USEPA slope factor for BaP [21]. There are only a few published human health risk assessments of coal tar. Two studies examined risks due to consumption of groundwater contaminated by hypothetical coal tars $[13,15]$ and a third focused on surface water and soil exposure risks on five selected hydrocarbons at a coal-tar contaminated site. While this latter study used field data, only one of the selected compounds was carcinogenic and the surface water was not used for consumption or irrigation [22]. Other than this one limited study, there is no readily available information in the literature on risk assessments of actual coal tar field samples, nor is there any information on how the composition of coal tar impacts human 
Table 2. Health effects and corresponding levels of confidence in the data for toxic and carcinogenic compounds identified in the coal tars.

\begin{tabular}{|c|c|c|c|c|c|c|}
\hline \multirow{2}{*}{ Compound } & \multicolumn{3}{|c|}{ Toxic $^{(a)}$} & \multicolumn{3}{|c|}{ Carcinogen $^{(a)}$} \\
\hline & Effect & $\begin{array}{c}\text { Test } \\
\text { species }\end{array}$ & $\begin{array}{l}\text { Confidence } \\
\text { in RfD }\end{array}$ & Effect & Test species & Classification $^{(\mathbf{b})}$ \\
\hline Benzene & $\begin{array}{l}\text { Decreased lymphocyte } \\
\text { count }\end{array}$ & Rats $^{(c)}$ & Medium & Lukemia & Human & A \\
\hline Toluene & Increased kidney weight & Rats & Medium & & & Inadequate \\
\hline Ethylbenzene & $\begin{array}{l}\text { Liver and kidney } \\
\text { toxicity }\end{array}$ & Rats & Low & & & $\mathrm{D}$ \\
\hline $\mathrm{m} / \mathrm{p}$-Xylenes & $\begin{array}{l}\text { Decreased body weight, } \\
\text { increased mortality }\end{array}$ & Rats & Medium & & & Inadequate \\
\hline Styrene & $\begin{array}{l}\text { Red blood cell and liver } \\
\text { effects }\end{array}$ & Dog & Medium & & & Not assessed \\
\hline 0 -Xylene & $\begin{array}{l}\text { Decreased body weight, } \\
\text { increased mortality }\end{array}$ & Rats & Medium & & & Inadequate \\
\hline Naphthalene & $\begin{array}{l}\text { Decreased mean } \\
\text { terminal body weight in } \\
\text { males }\end{array}$ & Rats & Low & & & $\mathrm{C}$ \\
\hline 2-Methylnaphthalene & $\begin{array}{l}\text { Pulmonary alveolar } \\
\text { proteinosis }\end{array}$ & Mice & Low & & & Inadequate \\
\hline Acenaphthene & Hepatotoxicity & Mice & Low & & & Not assessed \\
\hline Fluorene & $\begin{array}{l}\text { Decreased red blood } \\
\text { cell count }\end{array}$ & Mice & Low & & & $\mathrm{D}$ \\
\hline Anthracene & No observed effects & Mice & Low & & & $\mathrm{D}$ \\
\hline Fluoranthene & $\begin{array}{c}\text { Nephropathy, increased } \\
\text { liver weights }\end{array}$ & Mice & Low & & & $\mathrm{D}$ \\
\hline Pyrene & Kidney effects & Mice & Low & & & $\mathrm{D}$ \\
\hline Benz[a]anthracene & Not Assessed & & & Tumors & Mice & B2 \\
\hline Chrysene & Not Assessed & & & $\begin{array}{c}\text { Carcinomas, malignant } \\
\text { lymphoma, } \\
\text { chromosomal } \\
\text { abnormalities }\end{array}$ & $\begin{array}{l}\text { Mice and } \\
\text { hamsters }\end{array}$ & B2 \\
\hline Benzo[b]fluoranthene & Not Assessed & & & Tumors & Mice & B2 \\
\hline Benzo[k]fluoranthene & Not Assessed & & & $\begin{array}{l}\text { Tumors and lung } \\
\text { adenoma }\end{array}$ & Mice & B2 \\
\hline Benzo[a]pyrene & Not Assessed & & & $\begin{array}{l}\text { Forestomach, squamous } \\
\text { cell papillomas and } \\
\text { carcinomas }\end{array}$ & $\begin{array}{l}\text { Mice and } \\
\text { rats }\end{array}$ & B2 \\
\hline Indeno[1,2,3-cd]pyrene & Not Assessed & & & Tumors & Mice & B2 \\
\hline Dibenz[a,h]anthracene & Not Assessed & & & Carcinomas and tumors & Mice & B2 \\
\hline Benzo[g,h,i]perylene & Not Assessed & & & $\begin{array}{l}\text { Papillomas and } \\
\text { carcinomas }\end{array}$ & Mice and rats & $\mathrm{D}$ \\
\hline
\end{tabular}

(a) Data from the USEPA IRIS database [20]; (b) 1986 USEPA Guidelines [39]: A (Human carcinogen); B2 (Probable human carcinogen based on sufficient evidence in animals and inadequate or no evidence in humans); C (Possible human carcinogen); and D (Not classifiable as to human carcinogenicity). 2005 USEPA Guidelines [37]: Inadequate (inadequate information to assess the carcinogenic potential); (c) Human effects determined from an occupational inhalation study [20].

health risks.

Assessment of human health risks imposed by environmental contaminants typically follows the four-step process formalized in 1983 by the National Research Council [23] and the end result is a baseline assessment of health risks in the absence of any remedial action. Risk assessment is often performed in conjunction with the process of risk management, which involves remediation of the environmental contaminants to risk-based concentration levels. Standardized methods have been 
developed to combine these processes, including the ASTM Risk-Based Corrective Action (RBCA) process $[24,25]$ and the USEPA Soil Screening Guidance (SSG) [26,27]. The RBCA and SSG processes both use similar three-tiered approaches. Tier 1 is a simple screening process that uses conservative exposure assumptions, such as direct ingestion of water at chemical equilibrium with the source contaminants (e.g., coal tar), and this provides a conservative means to identify contaminants of potential concern and to remove from consideration sites that pose no health risks. The latter two tiers involve more site-specific fate and transport modeling, with Tier 2 involving simple analytical models and Tier 3 typically consisting of extensive numerical modeling.

While the RBCA and SSG processes were not specifically developed for scenarios where NAPLs such as coal tar are present, their approaches do not preclude investigation of NAPLs as long as specific NAPL processes are accounted for in the analysis [11,13,26,27]. For coal tars, one key process that must be accounted for is the effects of coal tar composition on the apparent solubility of the individual constituents, which is typically modeled via application of Raoult's law [11,13,28-30].

The purpose of this paper is to develop and apply a Raoult's law-based Tier 1 screening approach, to use it to provide insight into the environmental risks posed by coal tar contamination of groundwater, and to examine how compositional differences in coal tars may impact human health risks. This study uses field data from ten coal tar samples obtained from former manufactured gas plants in the eastern United States, with the tars exhibiting a wide range of chemical compositions. The car- cinogenic and toxic risks to human health from ingestion of coal tar-contaminated groundwater were evaluated following the Tier 1 assumptions in the ASTM RBCA and USEPA SSG methodologies, with coal tar composition accounted for by using a Raoult's law-based approach. It should be noted that the USEPA is currently revisiting its 1993 guidelines for risk assessment of PAHs [19,31] and both the 1993 guidelines and the 2010 draft technical document were applied and assessed in this study. The results from the ten coal tars were then used to perform a comparative assessment of the risks and this provided a simple correlation of carcinogenic and non-carcinogenic risks to readily-measured properties of the coal tars.

\section{Materials and Methods}

\subsection{Coal Tars}

Ten coal tar samples from nine former MGP sites in the eastern United States were used for this study. These samples ranged from free-flowing coal tar with apparent viscosities near that of water to thick, taffy-like coal tar that did not flow readily under the force of gravity. Detailed physical and chemical analyses of the ten coal tars are provided elsewhere $[11,32]$. The coal tar chemical compositions of relevance to this study are provided in Table 3 and the average molecular weights of the coal tars are provided in Table 4.

\subsection{Risk Assessment Methodology}

The risk assessment methodology used here is based on human consumption of water in chemical equilibrium with the coal tar. This is the initial screening approach used in tiered methodologies, including the ASTM RBCA methodology $[24,25]$ and the USEPA SSG process $[26,27]$. When considering water contaminated by dissolved coal tar constituents, the dose of constituent $i$ taken up by a human drinking the contaminated water, Dosei $(\mathrm{mg} / \mathrm{kg}-\mathrm{d})$, is defined as [33,34]:

$$
\text { Dose }_{i}=C_{a q}^{i} \frac{I r \cdot E f \cdot t_{e d}}{B w \cdot A t}
$$

where $C_{a q}^{i}$ is the aqueous concentration of coal tar constituent $i(\mathrm{mg} / \mathrm{L}) ; I r$ is the ingestion rate $(\mathrm{L} / \mathrm{d}) ; E f$ is the exposure frequency $(\mathrm{d} / \mathrm{yr}) ; t_{e d}$ is the exposure duration (yr); $B w$ is body weight ( $\mathrm{kg}$ ); and $A t$ is the averaging time (yr). When actual values for the exposure parameters are unavailable, the USEPA recommends standard values to be used in drinking water risk assessments. For adults, these values are $2 \mathrm{~L} / \mathrm{d}$ for ingestion rate, $350 \mathrm{~d} / \mathrm{yr}$ for exposure frequency, $30 \mathrm{yrs}$ for time of exposure, and $70 \mathrm{~kg}$ for body weight [26,33-36]. The averaging time depends on the type of risk assessment. For carcinogenic risks it is equal to $70 \mathrm{yrs}$ and for non-carcinogenic risks it is equal to the exposure duration [33-37].

When considering carcinogenic risks, a probabilistic approach is applied where the incidence, but not severity, of the cancer increases with dose and this is typically represented with a linear model relating dose to risk. With this formulation, the carcinogenic risk of component $i$, Risk $_{i}$ (unitless), is defined as [33,37]:

$$
\text { Risk }_{i}=S F_{i} \cdot \text { Dose }_{i}
$$

where $S F_{i}$ is the slope factor of component $i(\mathrm{~kg}-\mathrm{d} / \mathrm{mg})$. The USEPA maintains a database of slope factors for known and suspected carcinogens in the Integrated Risk Information System (IRIS) database [20]. Slope factors for the carcinogenic aromatic hydrocarbons are provided in Table 1. The carcinogenic risks of PAHs are complicated by the fact that while seven PAHs are listed by the USEPA as probable human (B2) carcinogens (Table 2), a slope factor has only been defined for benzo[a]pyrene (BaP) $[19,20]$. 
Development of a Raoult's Law-Based Screening-Level Risk Assessment Methodology for Coal Tar and Its Application to Ten Tars Obtained from Former Manufactured Gas Plants in the Eastern United States

Table 3. Concentrations of carcinogenic and toxic compounds identified in the coal tars (Units are in mg/kg).

\begin{tabular}{|c|c|c|c|c|c|c|c|c|c|c|}
\hline \multirow{2}{*}{ Compound } & \multicolumn{10}{|c|}{ Coal Tar ${ }^{(a)}$} \\
\hline & 1 & 2 & $4 M$ & $4 \mathrm{H}$ & 5 & 6 & 7 & 8 & 9 & 10 \\
\hline Benzene & 47.5 & 984 & 514 & 3390 & 523 & 964 & 986 & 1690 & 1360 & 233 \\
\hline Toluene & 210 & 3690 & 3100 & 11,900 & 1000 & 3330 & 2840 & 6370 & 4270 & 458 \\
\hline Ethylbenzene & 48.4 & 2920 & 901 & 1990 & 251 & 647 & 1760 & 2590 & 3790 & 134 \\
\hline $\mathrm{m} / \mathrm{p}$-Xylenes & 284 & 3120 & 2920 & 8100 & 1160 & 3020 & 2100 & 4620 & 3400 & 638 \\
\hline Styrene & 183 & 954 & 2450 & 7480 & 467 & 508 & 1110 & 3410 & 337 & 265 \\
\hline o-Xylene & 148 & 1610 & 1600 & 4170 & 440 & 1620 & 1060 & 2180 & 1590 & 264 \\
\hline Naphthalene & 10,000 & 32,700 & 20,600 & 35,700 & 27,500 & 28,800 & 13900 & 56,100 & 68,200 & 22,200 \\
\hline 2-Methylnaphthalene & 4660 & 19,000 & 12,300 & 17,600 & 6860 & 27,000 & 8620 & 24,000 & 38,300 & 4230 \\
\hline Acenaphthene & 430 & 1880 & 612 & 1030 & 928 & 1330 & 559 & 959 & 2300 & 808 \\
\hline Fluorene & 2420 & 6320 & 2730 & 4440 & 2960 & 4540 & 1370 & 2540 & 9510 & 1770 \\
\hline Anthracene & 1670 & 5170 & 2780 & 4600 & 3090 & 4020 & 1210 & 2970 & 8310 & 2000 \\
\hline Fluoranthene & 2870 & 5240 & 2550 & 4150 & 6220 & 2390 & 1330 & 3070 & 8690 & 4230 \\
\hline Pyrene & 2100 & 7150 & 3200 & 5190 & 5110 & 4260 & 2200 & 4750 & 11,400 & 3980 \\
\hline Benz[a]anthracene & 1110 & 3600 & 1680 & 2720 & 2440 & 1210 & 1020 & 1950 & 4390 & 1800 \\
\hline Chrysene & 802 & 3930 & 1430 & 2380 & 2250 & 1080 & 979 & 1840 & 3850 & 1720 \\
\hline Benzo[b]fluoranthene & 481 & 1170 & 638 & 980 & 1630 & 329 & 389 & 735 & 1930 & 1040 \\
\hline Benzo[k]fluoranthene & 695 & 1650 & 712 & 1280 & 1780 & 413 & 419 & 1060 & 2420 & 1240 \\
\hline Benzo[a]pyrene & 678 & 2610 & 1150 & 1940 & 2340 & 816 & 864 & 1960 & 4100 & 1570 \\
\hline Indeno[1,2,3-cd]pyrene & 311 & 797 & 371 & 629 & 1270 & 202 & 295 & 671 & 1530 & 1110 \\
\hline Dibenz[a,h]anthracene & 93.9 & 346 & 151 & 254 & 366 & 80.4 & 124 & 222 & 463 & 79.1 \\
\hline Benzo[g,h,i]perylene & 351 & 1000 & 100 & 465 & 787 & 1400 & 251 & 487 & 898 & 1930 \\
\hline
\end{tabular}

(a) From Reference [32].

To provide guidance for carcinogenic risks for the PAHs that do not have slope factors, the USEPA developed relative potency factors that relate their doses to an equivalent $\mathrm{BaP}$ dose and then applies the $\mathrm{BaP}$ slope factor to those compounds [19]. This approach assumes similar modes of action by the PAHs and is considered a "dose additive" approach [16]. The BaP equivalent dose of component $i$ is defined as:

$$
\text { BaP }_{\text {eq }} \text { Dose }_{i}=\text { Dose }_{i} \cdot P F_{i}
$$

where $P F_{i}$ is the relative potency factor of component $i$. The potency factors for PAHs are described in the 1993 USEPA document Provisional Guidance for Quantitative Risk Assessment of Polycyclic Aromatic Hydrocarbons [19]. The USEPA is currently reviewing the potency factors for PAHs and the Office of Research and Development has developed a draft technical document titled
Development of a Relative Potency Factor (RPF) Approach for Polycyclic Aromatic Hydrocarbon (PAH) Mixtures (February 2010 Draft), which has recently been reviewed by the USEPA Science Advisory Board [31]. The USEPA relative potency factors following both the 1993 guidance and the 2010 draft guidance are provided in Table 1 and they were applied and compared in this study.

Using the relative potency approach, the carcinogenic risk for each of the carcinogenic PAHs is then calculated as:

$$
\text { BaP }_{e q} \text { Risk }_{i}=S F_{B a P} \cdot B a P_{e q} \text { Dose }_{i}
$$

The equivalent benzo[a]pyrene risk is then the sum of the individual B2 PAH risks:

$$
B a P_{e q} R i s k=\sum_{i} B a P_{e q} R_{i s k}
$$


Table 4. Coal tar average molecular weight, total carcinogenic risk and hazard quotient for each of the ten coal tars.

\begin{tabular}{|c|c|c|c|c|}
\hline \multirow[b]{2}{*}{$\begin{array}{c}\text { Coal } \\
\text { tar }\end{array}$} & \multirow{2}{*}{$\begin{array}{c}\text { Average } \\
\text { molecular } \\
\text { weight }^{(a)} \\
(\mathrm{g} / \mathrm{mole})\end{array}$} & \multicolumn{2}{|c|}{ Carcinogenic risk $\left(\times 10^{-3}\right)$} & \multirow[b]{2}{*}{$\begin{array}{c}\text { Hazard } \\
\text { index }\end{array}$} \\
\hline & & $\begin{array}{c}1993 \\
\text { guidelines }\end{array}$ & $\begin{array}{c}2010 \text { draft } \\
\text { technical } \\
\text { document }\end{array}$ & \\
\hline 1 & 2143 & 1.63 & 2.00 & 54.5 \\
\hline 2 & 392 & 5.76 & 5.92 & 88.4 \\
\hline $4 \mathrm{M}$ & 990 & 7.59 & 7.78 & 126.8 \\
\hline $4 \mathrm{H}$ & 728 & 36.5 & 36.7 & 453.0 \\
\hline 5 & 3213 & 25.4 & 26.7 & 397.1 \\
\hline 6 & 621 & 8.86 & 8.95 & 141.3 \\
\hline 7 & 1099 & 16.0 & 16.2 & 207.1 \\
\hline 8 & 741 & 18.6 & 18.7 & 277.2 \\
\hline 9 & 316 & 6.43 & 6.62 & 110.9 \\
\hline 10 & 2303 & 8.23 & 8.76 & 155.5 \\
\hline
\end{tabular}

(a) From Reference [11].

The approach taken for non-carcinogenic compounds considers the severity of the toxic response to increase with dose above a certain threshold dose, called the Reference Dose, and below this threshold there is no toxic effect. The severity of the toxic response is represented by the Hazard Quotient, $H Q_{i}$ (unitless), which is the ratio of the ingested dose to the Reference Dose [33]:

$$
H Q_{i}=\frac{\text { Dose }_{i}}{R f D_{i}}
$$

where $R f D_{\mathrm{i}}$ is the Reference Dose for component $i(\mathrm{mg} / \mathrm{kg}-\mathrm{d})$. Current Reference Doses can be found in the USEPA IRIS database [20], and those for aromatic hydrocarbons present in coal tar are provided in Table 1.

For chemical mixtures, the approach currently recommended by the USEPA for combining the risks depends on the similarity of the chemicals $[16,33]$. For those chemicals which are toxicologically similar the "dose additive" approach is used and here the risks are added together. PAHs are an example of this for carcinogenic chemicals and the dose additive approach is used in Equations (3)-(5).

For carcinogenic chemicals that are toxicologically independent, the "response additive" approach is used, where the responses, rather than the doses, are summed. For exposure to multiple carcinogenic chemicals with independent modes of action, the response additive approach is defined by the probabilistic expression [16]:

$$
\text { Total Risk }=1-\prod_{i}\left(1-\text { Risk }_{i}\right)
$$

For coal tar, the benzene and benzo[a]pyrene carcinogenic effects are independent [20] (see Table 2). Then following Equation (7), the total carcinogenic risk is:

$$
\text { Total Risk }=1-\left(1-\text { BaP }_{e q} \text { Risk }\right) \cdot(1-\text { Benzene Risk })
$$

For total risks $<0.1$ Equation (8) is well approximated by [33]

$$
\text { Total Risk }=\text { BaP } P_{e q} \text { Risk }+ \text { Benzene Risk }
$$

which is a form that has been used in earlier studies [13, 15].

For chemical mixtures with similar toxicological effects, the total non-carcinogenic risk is calculated as the Hazard Index, $H I$, which is defined as the sum of the individual Hazard Quotients [16,33]:

$$
H I=\sum_{i} H Q_{i}
$$

When the chemical mixture contains chemicals having different toxicological effects, the USEPA recommends developing a separate Hazard Index for each effect [16, 33]. With the exception of benzene, the health effects of the toxic compounds in coal tar were assessed through animal studies and the level of confidence in the data is relatively low (Table 2). Because of this uncertainty, a conservative approach was used in this study, where a single Hazard Index was calculated for all the toxic compounds, and this approach has been deemed appropriate by the USEPA for screening level studies [33].

\subsection{Raoult's Law Aqueous Solubility}

The dose calculated via Equation (1) is a direct function of the aqueous concentration of each coal tar constituent. When considering a multi-component NAPL, such as coal tar, at chemical equilibrium with water, it is important to know that the various coal tar constituents are not present in the water at their aqueous solubility. Rather, they are present at their Raoult's law solubility $[8,11,13$, 28-30,38], which can be written as:

$$
C_{a q}^{i}=\chi_{i} \frac{C_{s o l}^{i}}{F R_{i}}
$$

where $\chi_{i}$ is the mole fraction of component $i$ in the coal $\operatorname{tar} ; C_{s o l}^{i}$ is the aqueous solubility of component $i(\mathrm{mg} / \mathrm{L})$; and $F R_{i}$ is the solid/liquid reference fugacity ratio of component $i$. Fugacity ratios can be obtained from the literature [14] or calculated as outlined in Peters and Luthy [8]. The mole fraction of component $i$ can be written as [11]:

$$
\chi_{i}=C_{c t}^{i} \frac{\overline{M W}_{c t}}{M W_{i}}
$$

where $C_{c t}^{i}$ is the concentration of component $i$ in the 
to Ten Tars Obtained from Former Manufactured Gas Plants in the Eastern United States

coal tar $(\mathrm{g} / \mathrm{g}) ; M W_{i}$ is the molecular weight of component $i$ (g/mole); and $\overline{M W}_{c t}$ is the average molecular weight of the coal tar (g/mole).

Raoult's law has been shown to accurately represent behavior of aromatic hydrocarbons from coal tar NAPL [28-30,38]. Thus, given component concentrations and the coal tar average molecular weight, Equations (1) through (12) provide a means to calculate the risks from drinking water that is in chemical equilibrium with the coal tar. This approach provides a simple risk screening process based on the standard exposure assumptions of Tier 1 in both the ASTM RBCA methodology [24,25] and the USEPA Soil Screening Guidance [26,27]. The resulting carcinogenic risk and non-carcinogenic hazard index can then be used to assess if remediation or further site-specific fate and transport studies are warranted.

\section{Results and Discussion}

\subsection{Carcinogenic and Non-Carcinogenic Risks}

Individual carcinogenic risks for benzene (Equation (2)) and the PAHs (Equation (4)) are shown in Figure 1 for the ten coal tars. The carcinogenic risks ranged from $\sim 10^{-7}$ for chrysene (1993 guidelines) and benzo[g,h,i]perylene (2010 draft guidelines) to $\sim 10^{-2}$ for benzene. The risks across the ten coal tars exhibited very similar patterns, even though the coal tars had significantly different chemical compositions (Table 3) and average molecular weights (Table 4). Benzene by far presented the highest carcinogenic risk for all the coal tars, followed by BaP, fluoranthene, and indeno[1,2,3-c,d]pyrene, While the trends were the same for all the coal tars, the total carcinogenic risks (Equation (8)) showed variations of over an order of magnitude between the ten tars (Table 4). The total risks ranged from $1.6 \times 10^{-3}$ to $3.7 \times 10^{-2}$ and in all cases the total risks from this screening-level analysis were well above the EPA threshold of $10^{-4}[33,36]$.

Taking a closer look at the data in Tables $\mathbf{1}$ and $\mathbf{3}$, it may be expected that $\mathrm{BaP}$ would pose a higher risk that benzene. This is because 1) the $\mathrm{BaP}$ concentrations in nine of the ten coal tars were larger than the benzene concentrations (Table 3) and 2) the BaP slope factor is two orders of magnitude greater than that for benzene (Table 1). In fact, if the coal tar was ingested directly, BaP
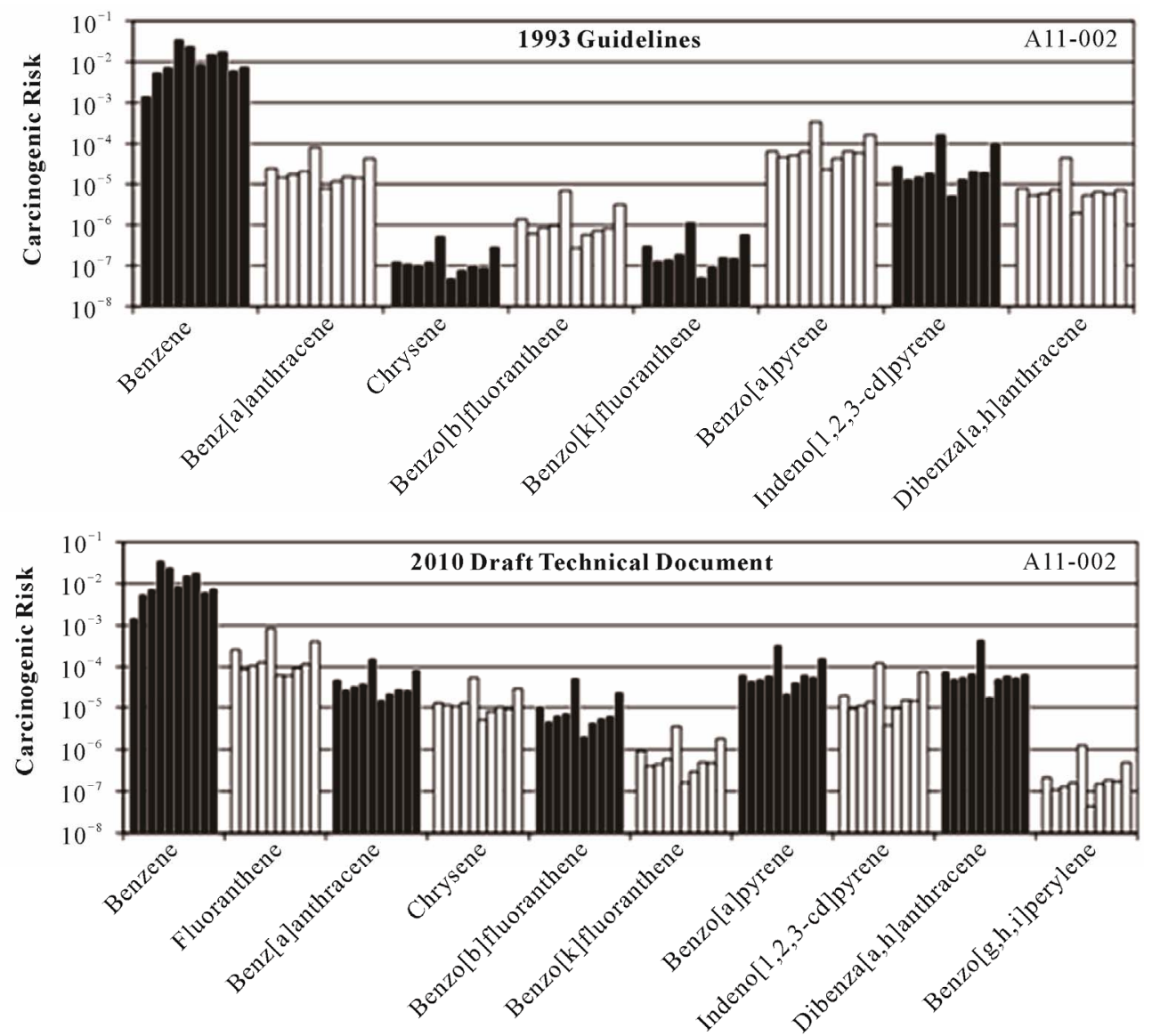

Figure 1. Individual carcinogenic risks for each of the carcinogenic compounds present in the ten coal tars following both the USEPA 1993 guidelines and the USEPA 2010 draft technical document. 
would have the larger carcinogenic risk. This result was found in a study where coal tar was directly fed to mice and the experimentally-derived coal tar slope factor was very similar to that of $\mathrm{BaP}[21]$.

However, in the current study, coal tar is not being directly ingested; rather it is water contaminated by the coal tar that is being ingested. In this case, the aqueous concentration drives the risk, not the specific concentration of an individual chemical within the coal tar, and for these coal tars the equilibrium aqueous concentration of benzene is significantly higher than those for BaP. For example, while the $\mathrm{BaP}$ concentration in coal tar 1 (678 $\mathrm{mg} / \mathrm{kg}$ ) is an order of magnitude greater than that of benzene $(47.5 \mathrm{mg} / \mathrm{kg})$, the Raoult's law aqueous solubility of benzene $(2.3 \mathrm{mg} / \mathrm{L})$ is four orders of magnitude greater than that of $\mathrm{BaP}(0.0008 \mathrm{mg} / \mathrm{L})$. It is the Raoult's law aqueous solubility that ultimately drives the risk and this is why the carcinogenic risks for benzene were approximately two orders of magnitude higher than those for BaP.

Similar results are seen in Figure 2 with the Hazard Quotients (Equation (6)) for each of the ten coal tars. The Hazard Quotients span four orders of magnitude, ranging from $\sim 0.01$ for anthracene to $\sim 100$ for benzene, and as with the carcinogenic risks, the patterns were very similar across the ten coal tars. Benzene provided the dominant risk, followed by naphthalene and 2-methylnaphthalene as major contributors. The Hazard Indices for the ten coal tars were then calculated using Equation (10) and the results are presented in Table 4. As seen in this table, the hazard indicies varied over an order of magnitude, ranging from 54.5 to 453 and all were well above the USEPA threshold of one $[33,36]$.

\subsection{Comparison of 1993 and 2010 Guidelines}

For this study, the relevant differences between the USEPA's 1993 guidelines and 2010 draft technical document are the inclusion of two additional PAHs with potency factors (fluoranthene and benzo[g,h,i]perylene) and increased potency factors for most of the PAHs. With regards to the latter, the largest increases were with chrysene (two orders of magnitude) and dibenz-[a,h]anthracene (one order of magnitude).

The impacts of these changes on the carcinogenic risks of the individual compounds are summarized in Figure 3, which shows the geometric mean of the risks across the ten coal tars for each compound. Most notable is the inclusion of fluoranthene, where it has the second-highest carcinogenic risk with the 2010 draft guidelines. While there are large increases in some of the individual risks with the 2010 draft guidelines, there is very little difference in the total carcinogenic risks between the 1993 guidelines and 2010 draft guidelines between the coal tars (Table 4). This is because benzene is the dominant contributor, with approximately a two order-of-magnitude greater risk contribution as compared to the individual PAHs.

\subsection{Relationship of Risks to Coal Tar Properties}

Given the similarities in carcinogenic risks and non-carcinogenic Hazard Indices observed for the individual constituents across the ten coal tars (Figures $\mathbf{1}$ and 2), an analysis was performed to determine if there were any correlations of the total carcinogenic risk and Hazard Index (Table 4) with coal tar properties. However, no correlations were found with either the coal tar average molecular weight or with any of the concentrations of the individual constituents in the coal tars (Table 3), such as benzene or naphthalene.

The risks from ingestion of water in chemical equilibrium with coal tar are a function of the Raoult's law aqueous solubility of the individual components, which in turn are a function their mole fractions in the coal tar. Because of this relationship, strong correlations were found between the benzene mole fraction (Equation (12)) and both the total carcinogenic risk $\left(R^{2}>0.998\right)$ and the

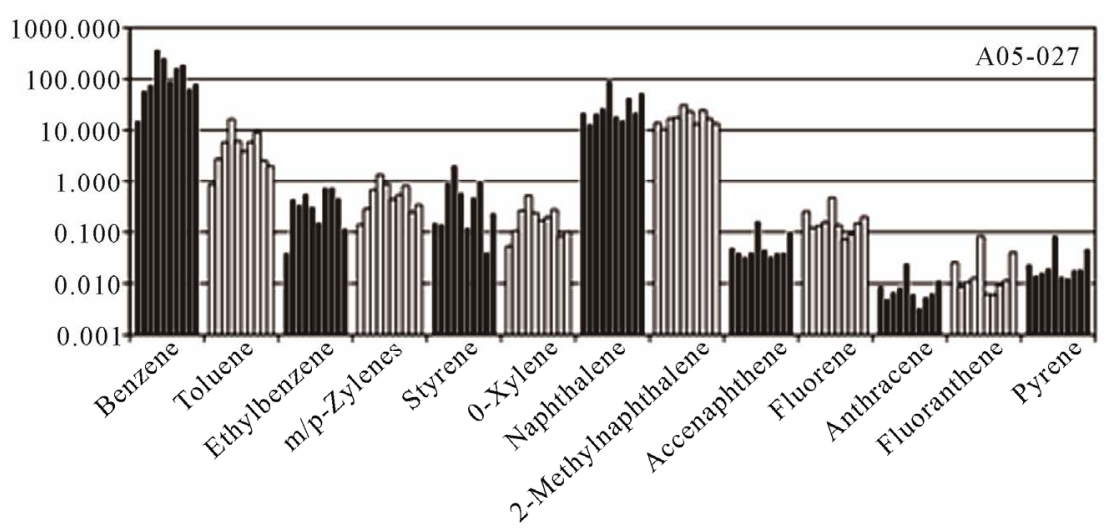

Figure 2. Hazard quotients for each of the toxic compounds present in the ten coal tars. 
Hazard Index $\left(\mathrm{R}^{2}=0.964\right)$. These correlations with the benzene mole fraction are depicted in Figure 4, and similar correlations can also be derived with the benzene aqueous concentration, which is a direct function of the mole fraction via Raoult's law (Equation (11)). No additional correlations were observed with the mole fractions of any other individual constituents. When plotted as a function of the benzene mole fraction, the carcinogenic risk (Figure 4) shows a near-zero intercept, indicating that the carcinogenic risks of these ten coal tars are dominated by benzene. In contrast, the Hazard Index has a non-zero intercept, and this is due to the relative contributions of naphthalene and 2-methylnaphthalene becoming larger as the benzene mole fraction decreases. This impact of the benzene mole fraction results in the total carcinogenic risk and Hazard Index being highly correlated for the ten coal tars examined here, and this relationship is shown in Figure 5.

\section{Summary and Conclusions}

The Raoult's law-based method developed in this study provides a rapid means to perform a Tier 1 screeninglevel risk analysis of coal tar contamination to groundwater. By applying this method to ten different coal tars, it was shown that the risk contributions by the individual compounds within the coal tars showed a very consistent trend among the ten tars (Figures 1 and 2). Benzene dominated the risks, even though its mole fraction in the coal tars was much lower than the other compounds, most notably benzo(a)pyrene. This is due to the high Raoult's law solubility of benzene and it resulted in benzene having both a two order-of-magnitude greater carcinogenic

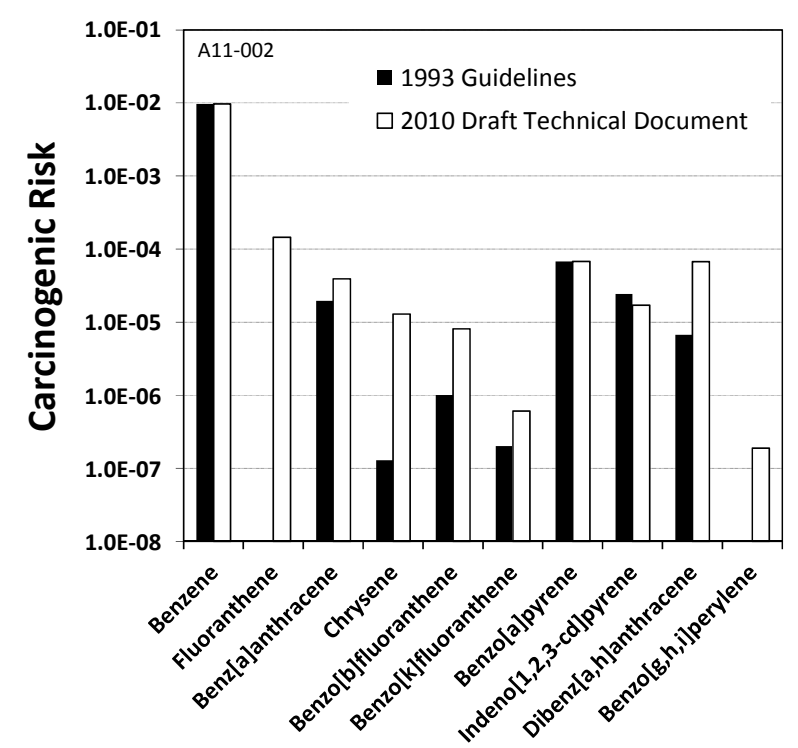

Figure 3. Comparison of the geometric means for each of the carcinogenic compounds in the ten coal tars (see Figure 1).

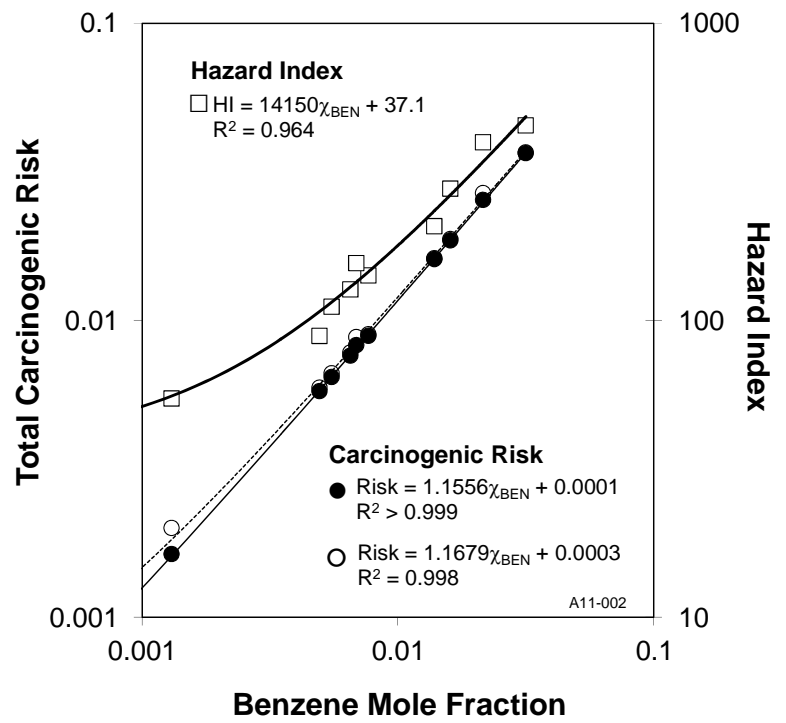

Figure 4. The total carcinogenic risk (•-1993 guidelines; $\bigcirc-2010$ draft technical document) and the hazard index ( $\square$ ) are both strong functions of the benzene mole fraction $\left(\chi_{\text {BEN }}\right)$.

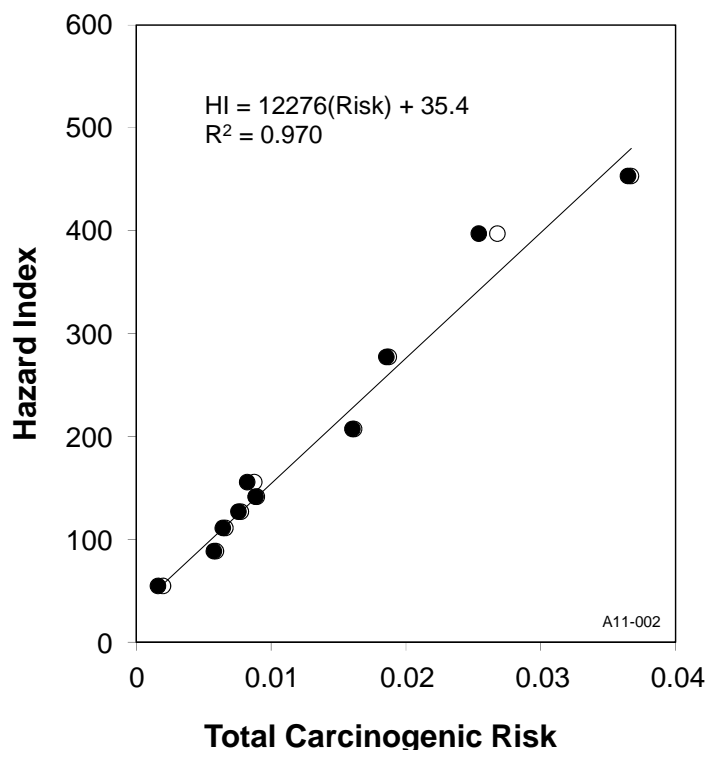

Figure 5. Carcinogenicity and toxicity are strongly correlated due to the contributions of benzene to both risks $(\bullet-$ 1993 guidelines; ○—2010 draft technical document).

risk and a one order-of-magnitude greater Hazard Quotient than any of the other compounds. Because of this, there were strong correlations between benzene mole fraction and both the carcinogenic risk and Hazard Index (Figure 4). These relationships provide a rapid means to estimate the overall Tier 1 (screening-level) risk posed to groundwater by coal tar.

Comparison of the current and draft USEPA PAH carcinogenic risk assessment guidance documents showed 
that the 2010 draft technical document potency factors result in a higher risk for the PAH's in the coal tar (Figure 3). This was especially pronounced for fluoranthene, which is not included in the 1993 guidance document. However, when considering the overall Tier 1 carcinogenic risk from the coal tars, there was very little difference between the 1993 and 2010 draft guidelines due to the dominance of benzene (Table 4).

Finally, it was shown the total carcinogenic risk and Hazard Index were well above the USEPA thresholds of $10^{-4}$ and one, respectively, for all ten coal tars, indicating that the presence of coal tar in the subsurface has the potential to result in significant human health risks.

\section{REFERENCES}

[1] USEPA, "US Production of Manufactured Gases: Assessment of Past Disposal Practices," EPA/600/S2-88/012, 1988.

[2] A. W. Hatheway, "Manufactured Gas Plants: Yesterday's Pride, Today's Liability," Civil Engineering, Vol. 67, No. 11, 1997, pp. 38-41.

[3] T. D. Hayes, D. G. Linz, D. V. Nakles and A. P. Leuschner, "Manufactured Gas Plant Sites," Amherst Scientific Publishers, Amherst, 1996.

[4] E. O. Rhodes, "The History of Coal Tar and Light Oil," In: A. J. Hoiberg, Ed., Bituminous Materials: Asphalts, Tars and Pitches, Interscience Publishers (John Wiley \& Sons), New York, 1966.

[5] R. Eng, "Survey of Town-Gas and Byproduct Production and Locations in the US (1880-1950)," EPA/600/7-85/004, 1985.

[6] M. Krasley, "Coal Tar Contamination of the Environment by the Manufactured Gas Industry. A Review," FL 354.551, 1990.

[7] C. J. Castaneda, "Invisible Fuel: Manufactured and Natural Gas in America, 1800-2000," Twayne Publishers, New York, 1999.

[8] C. A. Peters and R. G. Luthy, "Coal Tar Dissolution in Water-Miscible Solvents: Experimental Evaluation," Environmental Science \& Technology, Vol. 27, No. 13, 1993, pp. 1831-2843. doi:10.1021/es00049a025

[9] M. Zander, "Aspects of Coal Tar Chemistry. A Review," Polycyclic Aromatic Compounds, Vol. 7, 1995, pp. 209221. doi:10.1080/10406639508009625

[10] M. Zander and G. Collin, "A Review of the Significance of Polycyclic Aromatic Chemistry for Pitch Science," Fuel, Vol. 72, No. 9, 1993, pp. 1281-1285. doi:10.1016/0016-2361(93)90126-M

[11] D. G. Brown, L. Gupta, H. K. Moo-Young and A. Coleman, "Raoult's Law-Based Method for Determination of Coal Tar Average Molecular Weight," Environmental Toxicology and Chemistry, Vol. 28, No. 4, 2005, pp. 18861892. doi:10.1897/04-470R.1

[12] EPRI, "Chemical and Physical Characteristics of Tar Samples from Selected Manufactured Gas Plant (MGP) Sites,"
TR-102184, 1993.

[13] D. G. Brown, C. D. Knightes and C. A. Peters, "Risk Assessment for Polycyclic Aromatic Hydrocarbon NAPLs Using Component Fractions," Environmental Science \& Technology, Vol. 33, No. 24, 1999, pp. 4357-4363. doi:10.1021/es9902423

[14] D. Mackay, W. Y. Shiu and K. C. Ma, "Illustrated Handbook of Physical-Chemical Properties and Environmental Fate for Organic Chemicals," Lewis Publishers, Boca Raton, 1992.

[15] C. A. Peters, C. D. Knightes and D. G. Brown, "LongTerm Compositional Dynamics of PAH-Containing NAPLs and Implications for Risk Assessment," Environmental Science \& Technology, Vol. 33, No. 24, 1999, pp. 44994507. doi:10.1021/es981203e

[16] USEPA, "A Resource for MGP Site Characterization and Remediation,” EPA 542-R-00-005, 2000.

[17] R. G. Luthy, D. A. Dzombak, C. A. Peters, S. B. Roy, A. Ramaswami, D. V. Nakles and B. R. Nott, "Remediating Tar-Contaminated Soils at Manufactured Gas Plant Sites: Technological Challenges," Environmental Science \& Technology, Vol. 28, No. 6, 1994, pp. 266A-276A. doi: $10.1021 / \mathrm{es} 00055 \mathrm{a} 002$

[18] NIEHS, "The 8th Report on Carcinogens: 1998 Summary," 1998.

[19] USEPA, "Provisional Guidance for Quantitative Risk Assessment of Polycyclic Aromatic Hydrocarbons," EPA/ 600/R-93/089, 1993.

[20] USEPA, “Integrated Risk Information System,” 2011. www.epa.gov/iris

[21] D. W. Gaylor, S. J. Culp, L. S. Goldstein and F. A. Beland, "Cancer Risk Estimation for Mixtures of Coal Tars and Benzo(A)Pyrene," Risk Analysis, Vol. 20, No. 1, 2000, pp. 81-86. doi:10.1111/0272-4332.00008

[22] J. G. Bolten, P. F. Morrison, S. A. Resetar and K. A. Wolf, "Health Risk from a Coal Tar Disposal Site," 1988.

[23] National Research Council, "Risk Assessment in the Federal Government: Managing the Process," National Academy Press, Washington DC, 1983.

[24] ASTM, "Standard Guide for Risk-Based Corrective Action Applied at Petroleum Release Sites,” E1739-95, 1995.

[25] ASTM, "Standard Guide for Risk-Based Corrective Action," E2081-00, 2000.

[26] USEPA, "Soil Screening Guidance: User's Guide," EPA/ 540/R-96/018, 1996.

[27] USEPA, "Supplemental Guidance for Developing Soil Screening Levels for Superfund Sites," OSWER 9355.424, 2002.

[28] C. Eberhardt and P. Grathwohl, "Time Scales of Organic Contaminant Dissolution from Coplex Source Zones: Coal Tar Pools vs. Blobs," Journal of Contaminant Hydrology, Vol. 59, No. 1-2, 2002, pp. 45-66. doi:10.1016/S0169-7722(02)00075-X

[29] M. F. Khalil, U. Ghosh and J. P. Kreitinger, "Role of Weathered Coal Tar Pitch in the Partitioning of Polycyclic Aromatic Hydrocarbons in Manufactured Gas Plant Site 
Development of a Raoult's Law-Based Screening-Level Risk Assessment Methodology for Coal Tar and Its Application to Ten Tars Obtained from Former Manufactured Gas Plants in the Eastern United States

Sediments," Environmental Science \& Technology, Vol. 40, No. 18, 2006, pp. 5681-5687. doi:10.1021/es0607032

[30] L. Liu, S. Endo, C. Eberhardt, P. Grathwohl and T. C. Schmidt, "Partition Behavior of Polycyclic Aromatic Hydrocarbons between Aged Coal Tar and Water," Environmental Toxicology and Chemistry, Vol. 28, No. 8, 2009, pp. 1578-1584. doi:10.1897/08-276.1

[31] USEPA, “SAB Review of EPA's 'Development of a Relative Potency Factor (RPF) Approach for Polycyclic Aromatic Hydrocarbon (PAH) Mixtures (February 2010 Draft),', 2011.

[32] H. Moo-Young and D. Brown, "Laboratory Assessment of Leaching Potential of Coal Tar at MGP Sites," 1009425, 2004.

[33] USEPA, "Risk Assessment Guidance for Superfund. Volume 1. Human Health Evaluation Manual (Part A)," EPA/540/1-89/002, 1989.

[34] USEPA, "Guidelines for Exposure Assessment," EPA/
600/Z-92/001, 1992.

[35] USEPA, "Risk Assessment Guidance for Superfund. Volume 1. Human Health Evaluation Manual. Supplemental Guidance-Standard Default Exposure Factors. Interim Final Report," OSWER Directive 9285.6-03, 1991.

[36] USEPA, "Role of the Baseline Risk Assessment in Superfund Remedy Selection Decisions," OSWER Directive 9285.6-03, 1991.

[37] USEPA, "Guidelines for Carcinogen Risk Assessment," EPA/630/P-03/001B, 2005.

[38] M. Fraser, J. F. Barker, B. Butler, F. Blaine, S. Joseph and C. Cooke, "Natural Attenuation of a Plume from an Emplaced Coal Tar Creosote Source over 14 Years," Journal of Contaminant Hydrology, Vol. 100, No. 3-4, 2008, pp. 101-115. doi:10.1016/j.jconhyd.2008.06.001

[39] USEPA, "Guidelines for the Health Risk Assessment of Chemical Mixtures,”EPA/630/R-98/002, 1986. 